\title{
Competence of Biopesticide and Neem in
}

\section{Agriculture}

\author{
Preeti Acharya, Showkat Ahmad Mir, Binata Nayak ${ }^{*}$
}

School of Life Sciences, Sambalpur University, At/po- JyotiVihar, Burla; Dist- Sambalpur, Odisha, India.

\begin{abstract}
Neem plant is considered as the most useful traditional plant in India. The various properties of different parts of neem tree are used as insecticide, antifeedant, hormonal, antifungal, antiallergic, antidermatic, anti-inflammatory, antiscabic larvicidal and spermaticidal activity etc. In recent era the major challenge is to increase the food production without harming the environment and can control the pest. Since, last decades pesticides have become an integral component in sustainable agriculture and the modern day cultivation practices uses of chemical pesticides and fertilizers are in eliminable. Enormous use of different chemical pesticides in agricultural fields is resistant to most of the pests. So that the natural pesticides from A. indica are considered to be less harmful, biodegradability, least persistence, lest toxic to non-target organism, economic and used to combat insects, pests are not ruled out. Neem derived products play an essential role in the pest management, in agricultural fields such as crop and stored grains. Fruitful results of application of formulated neem based products in agriculture field will provide a cost effective technology to the farmers.
\end{abstract}

Keywords-Bio fertilizer, Biopesticides, Neem, Soil fertility.

\section{INTRODUCTION}

Agriculture is a significant sector for food, fibres, biofuels \& other products for the wellbeing of human life. In the context of the growing Indian population, apart from fulfilling the demands of food, agriculture plays vital role in improving the socio economic status of country. In the other hand, with the increase in human population along with the scarcity of land, people are using chemical fertilizers and pesticides for enhancing food productivity and crop yielding capacity which are the primary causes for the reduction in soil fertility and degradation [Liu et al., 2004].Neem plant namely Azadirachta indica commonly found in Indian subcontinents and belongs to family Meliceae. This tree grows rapidly and can reach a height of 15-20 meters in tropic and sub tropic climate, and also survive in dry and arid conditions. The barks of neem plant contain $14 \%$ of tannin; it is also strong in course fiber which is commonly used in ropes. In India $80 \%$ of neem oil is used in manufacturing of soaps. One of the most popular dishes namely veppampoo charu obtained from the shoots and flowers of neem are commonly used in Tamilnadu. The neem plant is used in medical treatment, and its oil is used in insecticides, lubricants, pesticides, and in variety of diseases such as diabetes and tuberculosis. The environment is adversely affected by the use of chemical fertilizer and pesticide like water hardness, development of insect resistance, genetic variation in plant, increase in the toxic level in food chain and other human health issues like skin cancer. These also cause water pollution due to the accumulation of nitrates by the breakdown of nitrogen fertilizer. Applying high level of chemical fertilizers \& pesticides on agriculture can gradually reduce the growth of beneficial microorganism in soil. To make an eco-friendly plant protection field through an integrated pest management (IPM), it is necessary to introduce the substitutes of chemical fertilizers and pesticides called bio fertilizer and bio pesticide which are the inoculants of soil microorganism, which enrich the soil nutrient level \& establish the symbiotic relationship with plants by producing nitrogen \& phosphorous nutrient in the soil and harnessing the foresaid challenges [Dutta, 2015]. Biofertilizers are the substances which contain bio-organisms which colonize and supports to promote the growth of plants by supplying the primary nutrient. They have the ability to synthesize important nutritional element from non-usable to usable form. The study says that the application of bio-fertilizer to the seed or soil improves the yield by 10-20\% without harming the soil \& environment [Roychowdhury et al., 2014].

\section{PESTICIDES}

Pesticides are toxic chemical compounds are used in agriculture, horticulture, olericulture, floriculture, to kill the pests, improve the quality of plant and increase the crop yield. Pesticides are used in public health to kill the vector of diseases such as mosquito and in agriculture to kill pests which cause crop damage. Ideal pesticides must be lethal to targeted pest but nontoxic to non-target species including man. There are two outcomes from the use of pesticide on agriculture field both beneficiaries as well as hazardous impact. Benefits of pesticide include improvement of productivity, protection of crop losses, 
and vector disease control improved quality of food [Aktar et al., 2009]. Pesticides can be up two types based on the presence of active ingredient, such as Synthetic pesticides and Bio pesticides:

\subsection{Synthetic Pesticides:}

The synthetic are placed in different groups like Organ chlorines, Organophosphates, Phenoxies, Triazines and Thiocarbamates etc. According to different survey in European nation, some pesticides have hazardous impact on food stock, soil, water level, environment and finally human. It has been reported that pesticides Acephate, chlorpyriphos, methylated chloropyriphos, Methamidophos, Iprodione, Procymidone, Chlorothalonil, Benomyl and Moneb group have dangerous effect on fruits like apple, strawberries and grapes. Every sample contained some amount of residue of these applied pesticides [Aktar et al., 2009]. These pesticides are unavoidable imputes in our ecosystem and olericulture. India used maximum amount of synthetic pesticides in comparison to world. In India, about $76 \%$ insecticides are used whereas about $44 \%$ of insecticides are used in worldwide [Mathur et al., 1999].

\subsection{Biopesticide: An excellent alternative of chemical pesticide}

As we know pesticides are the toxic substances that kill the weeds, insects, fungus, and rodents. It is also used to manage the pest problem around the world [Lewis et al., 1997]. Pesticides show a extensive range of human health risks from temporary to permanent impact. Among these conditions, acute conditions include nerve dysfunction, skin and eye irritation and long term chronic effects lead to cancer. In comparison to pesticides, bio pesticide are an eco-friendly nontoxic natural type of pesticides, derived from natural substances like plants, bacteria \& minerals which has the capacity to control pests without affecting the environment. It was reported in 2014 that about 430 bio pesticides and 1320 active products has been registered for use in agricultural land [Roychowdhury $e t$ al., 2014]. Bio pesticides have the properties like target pest specific and their close relatives, harmless to human beings and other beneficial organisms, and never cause pollution [Rabindra, 2005; Thakore, 2006]. So it is a major component of IPM (Integrated pest management) programme. According to the presence of different key components, bio pesticides are broadly classified as microbial bio pesticide (which include bacterial, fungal, viral), biochemical bio pesticide which include insect pheromone, different components of plant, growth regulatory hormone and the others are the formulated product of bio pesticide [Vinod et al., 2015]. The challenges for bio pesticide industries are to develop a fruitful, safe and multifacted eco-friendly products
[Mukhopadhay et al., 1992; Kalra and Khanuja, 2007; Prabhat et al., 2014].

\subsubsection{Microbial bio pesticide}

The active components in microbial bio pesticide are naturally evolved bacteria or genetically modified bacteria, fungi, viruses and protozoans. About 74\% bacterial bio-pesticides, $10 \%$ of fungal pesticides, $5 \%$ of viral bio-pesticides and others include about $3 \%$ for all type of crops [Thakore, 2006]. Till now about 72 components of micro-organisms have been registered by USEPA (United States Environmental Protection Agency) which include 35 bacterial products, 15 fungal, 8 plants incorporated protectants (PIPs), 6 nonviable microbial bio-pesticides, 1 protozoan, 1yeast and 6 viruses.

\subsubsection{Biochemical pesticide}

Biochemical pesticides are different from the conventional pesticide. The key components evolve naturally, a mixture comprising essential oil, insect pheromone etc. [Gelernter, 2006]. The hormone released from insects to communicate other members of same species is called as insect pheromones (semiochemicals). These chemicals are the type of decoder produced by the living organism or synthetic analogues which cause behavioural responses in the same or other species. The pheromones are used in pest management without killing the target pest but by attracting the pest towards the lethal pesticide or by initiating mating disruption. As it monitors the larger group of pest, it is the part of IPM system [Thakore, 2006]. The mixture of chemical component derived from plants and used as bio-pesticide are more diverse with respect to target pest, mode of action and their composition [Kovach et al., 2012]. Different plant products have different modes of action on target organism: the fragrance of some plant extracts attract the toxic insects but other used as deterrent. Lemongrass oil, cause the degradation of some weeds. Some products cause suffocation while some other products increase the immune system of crops naturally. The important components for the proper growth of plants are plant hormones \& growth regulators that accelerate or retard the growth of plant naturally. Along with bacterial bio-pesticide, fungal bio-pesticide, insect pheromone and some growth regulators of insect also alter the growth \& development of insects, along with this some insecticides having juvenile hormone are also used [Vinod et al., 2015]. Some chitin synthesis inhibitors are used as insecticide which decreases the ability of insect for further synthesis of new exoskeleton [Karen et al., 2009].

\subsubsection{Formulated Bio pesticides}

The key components of formulated bio-pesticides are all the microbes and plant products. In case of bio-pesticide processing, some problems are related to presence of other inert ingredients along with the active ingredients. 
Different survey have been carried out to study the particular bio-pesticidal effects on pests in various agricultural crops [Rahman \& Motoyama, 2000] such as repellant as well as insecticidal effect from entire garlic clove, its rubbed product and buoyant extract of garlic on two stored products, maize weevil (Sitophilus zeamais) and red flour beetle (Tribolium casteneum). Alliin highly reactive and unstable volatile compound present in garlic is converted to allicin, pyruvate and ammonia by the activity of an enzyme called allinase when garlic is chopped [Salas, 2001]. These allicin have the aromatic property which repels the target pest, but the mechanism is unsure. From some studies it has been observed that some plant material like leaves of neem, pongum, citrus, nocli, tulsi, fly ash, castor oil, red earth are strongly effective on the survival of $C$. Maculates flourishing the green gram [Dhakshinamoorthy and Selvanarayana., 2002]. Different doses of neem (Azadirachta indica), Bergera (Bergera koenigii), akk (Calotropis gigentea), ipoma (Ipoma reptans), chilli (Capsicum amanda), and mustard (Brassica campestris) have the strong effects against sitophilis oryzae [Petel et al., 2004]. Repulsive activities of some essential oil of aromatic plants were also analyzed by GC-MS (gas chromatography - mass spectrometry) against sitophilus zeamais (Coleoptera: curculinonidae) [Nerio et al., 2009].

\subsubsection{Neem in Agriculture}

Neem is considered as renewable resource with the potential in solving agricultural, environmental and public health problems. The common properties of neem are its non-toxicity; so they are beneficial in plant conservation and management. Neem derived products such as neem fruit, neem oil, neem seed cake and leaf extract used as bio-pesticide, fungicide and organic manure has been applied because of their different mode of action to control the insects, plant pathogen, pest which have the resistance against chemical pesticides. Studies say that neem can regulate around 300 species of insects. The most common form of neem used as pesticide in organic agriculture are the emulsifiable concentrate (EC) due to its biodegradable nature as well as it is easily mixes with synthetic pesticides and enhances their action. Now a day's dried neem extract is mixed with the stored grain, to prevent further proliferation of storage pest and even the insects stop feeding on them due to its anti-feeding property like, the most popular bio-pesticide Neem seed kernel extract (NSKE 5\%) which is composed of well dried form of neem seed kernel, distilled water, detergent and neem oil (multineem) are used against chick pea pod borer Helicoverpa armigera [Bhatt and Patel, 2001]. Neem products intercede at various phases of the insect's life. The main function is to paralyze the activity of pests instead of wiping out the pests. Due to the powerful insect growth regulatory (IGR) activity of different parts of neem, they are now recognised as more covetable product than a rapid clash synthetic pesticide in integrated pest management programmes. Not only Neem obeys all precedences among environmental objectives, this particular plant is also perhaps the utmost symbolic example of how nature can blend divergent activities i.e., the action of de-oiled Neem cake as a pesticide cum fertilizer.

\subsubsection{Neem as an Insecticide}

Neem trees are invincible produce various defensive chemicals during pest attack which act as repellent, antifeedant, ovipositional deterrent, growth inhibitor, toxicant [Saxena et al., 1989].There are several application of different parts of neem tree in the field of ayurvedic medicine, as effective dentifrice [Larson, 1989], neem cake (remained part after oil extraction) as an effective fertilizer and animal feed. Azadirachtin (tetranortritterpenoid) one of the major active components which is the most potent natural insect antifeedant [Isman et al., 1990]. It is a mixture of seven isomers named as Azadirachtin A-G. Among all, isomer E is most effective against insect growth regulator. Azadirachtin is highly unstable and stored at $-40^{\circ} \mathrm{C}$ are not applied directly to the field. Oil based extracts stabilize these biologically active compounds. So the commercial azadirachtin preparation is more advantageous over pure azadirachtin [Isman et al., 1990a].

Neem extract has been used in over 195 insect species and some rebellious insects are also controlled by the neem extract application [Salma et al., 2011]. Formulated neem product has significant effect against eggs of peach fruit fly (Bactrocera zonata) but has no effect on good insects like pollinator insects, bees and other useful organism [Salma et al., 2011].The insecticidal effect of Botanical toxin (Bacillus thuringiensis) and agricultural insecticide (Azadirachta indica and Vitex negundo) on the lactate dehydrogenase enzymatic activity in rice leaf folder called as Guenee (Cnaphalocrocis medinalis) was studied [Nathen et al., 2006]. The combined effect of both bacteria and insecticides even in low concentration decreases the LDH activity strongly. This indicates that combinational product is an efficient enzyme inhibitor [Kumar, 2015].

Some of the studies are done by using aqueous form of neem seed powder on the survival, improvement and growth of Aphid (Aphis gussypii) Glover which is the most perinicious pest on cotton causing direct or indirect loss [Chinaberry and Jehu, 2001].This aphid normally live superficially on leaves, feed the phloem part and causes around 50 types of diseases in plant. Biological insecticides are used against these aphids instead of using 
aphid resistant chemical pesticide [Weathersbee, 1997; Kabissa et al., 1996; Mann et al., 2001]. The negative effects of different concentration of azadirachtin on different parameters like development \& survival of nymph, number of molts of aphids A. gossypii has been checked [Stark and Rangus, 1994]. It was found that the fertility of various aphids like A.pisum on faba bean [Stark and Rangus, 1994; Stark and Wennergren, 1995] and Myzus persicae on sweet pepper were reduced at the highest concentration of neem extract. Neem extracts show high mortality rate, decreasing fertility, growth inhibitory activity on more than 400 insect species from different orders like Diptera, Hymenoptera, Coleoptera, Lepidoptera, orthoptera and Hemiptera etc [Ragsdale $e t$ al., 2004; Liu et al., 2004]. As neem extract is efficient to control several aphids in the field, so these are the most significant product to be used as biological pesticide.

The neem product Azadirachtin affect the activity of enzyme ecdysone by suppressing the moulting or ecdysis process of insects by entering into insect's larva through feeding and restrict the passage of larva to pupal stage, thus leading to death. The different parameter like survivorship, development, fecundity of soybean aphid (Aphis glycine) and its predator named Harmonia axyridis are also are affected by the action of neem seed oil and azadirachtin. Azadirachtin\& neem seed oil are two key components which have been proven most fruitful agent, against the aphids like Brown citrus aphid, Toxoptera citricida (Kirk lady) by increasing in nymph as well as adult mortality and decreasing adult fecundity in all trial concentration [Tang et al., 2002]. Along with this, neem seed oil has some muffling effect on pea aphid, Acyrthosiphon pisum (Harris) nymphal mortality [Stark and Walter, 1995]. Based on the aphid mortality neem oil and its processed product are more efficient than azadiractin [Adan et al., 1998].

\subsubsection{Neem as an ovipositional deterrent}

Neem (Azadiracht indica, A.Juss, Meliaceae) as a plant based pesticides [Elisinary and Rizk, 2002] has an ovipositional deterrent activity on some pest like Bactrocera carambolae (fruit fly) which decreases economic value of fruits and vegetables. It is also used against the cabbage moth, Mamestra brassicae [Joger et al., 2009], peach fruit-fly (B. Zonata) [Mohamoud and Shoeib, 2008] and potato tuber moth, phthorimaea opercullela [Elsinary and Rizk, 2002]. It has been found that neem leaves contain more polar components and the most dominant component found in $\mathrm{n}$-hexane extract of neem is nonacosane, which is made up of a group of saturated fatty acid having the negative impact on egg as well as egg producing capacity and durability of larvae of Stephanities pyriodes [Wang et al., 1999]. Nonacosane attracts different parasitoid like Trichogramma chilonis [Ananthakrishnan et al., 1991], T. Briasiliensis and T. exiguum [Kumar et al., 2011] and Cotesia plutellae [Kumar et al., 2012; Seenivasagan and Paul, 2011].

\subsubsection{Neem as Biofungicide}

Neem oil is used as fungicide, to prevent the germination of fungal spores. The neem based products are used as natural biofungicide in the branch and collar canker disease caused by tea plant pathogen. The extracts of neem have a suppressive effect on the fungal pathogen like Poriamonticolad infecting wood [Dhyani et al., 2004], Pyricularia oryzae infecting rice plant [Amadioha, 2000]. Components like Azadirachtin, nimbin , nimbidin and also some commercially available neem product like Achook, Bioneem, Nimbecidine, Neemark have the antifungal property against some pathogen like Fusarium oxysporium, Altanaria solani, Curvulata lunata, Helminthosporium sp. and Sclerotium rolfsii [Bonder et al., 1999]. Azadirachtin has significant inhibitory effect on the plant pathogenic fungi and acts as a most advance fungicide than Bavistin and mancozeb, the synthetic fungicide [Dubey and Kumar, 2009]. Beside this, neem oil also has the fungicidal property on some fungi like Botryiscinera.and Glomerella cingulata [Hirose et al., 2001]. Among the commercially available neem products, Nimbecidine is the oil based pesticide where the active ingredients are azadirachtin and other components like meliantrol, salnin, nimbin are used against the worms, weevils and wire worms of tomatoes [Schumutterer, 1990]. Another component of neem is Trilogy which is a clarified hydrophobic extract of neem oil, has multiple properties like insecticide, acaricide and fungicidal effect against the mildews on cucurbits [Meister, 1999]. It also acts as a growth regulatory agent and represses the growth of pathogen like Podosphaera xanthii on cucumber leaves [Aboellil, 2007]. Trilogy is more effective in bacteria like Pseudomonas xanthii at very low concentration as reported by [Polioakidou, 2005]. The growth inhibitory effect of nimbecidine is more than that of Trilogy in their higher concentration. Nimbecidine has an adverse effect on the growth parameter of $P$. theae and can be used by the farmers in the management of pest [Okigbo and Nmeka, 2005].

\section{CONCLUSION}

Now there is a need of cost effective, biodegradable, ecofriendly and potential, soft pesticide in agriculture field. As neem act as the most reliable source of pro-pesticide having no ill effect on human and animals, on agricultural product. So neem is used as organic fertilizer and pesticide for sustainable crop production. Neem based products play a crucial role in pest management, which acts across different pests of both crop field as well as 
stored grains like rice, wheat, corn, legumes, potato, tomato etc.

\section{REFERENCES}

[1] Aboellil, A.H. (2007). Trilogy, a product of Neem (Azadirachta indica), induces resistance in cucumber against (Podosphaeraxanthii). Reserve Journal of Microbiology, 2(5): 402-414.

[2] Adan, A., Soria, J., DelEstal, P., Sanchez-Brunete Cand Vinuela, E. (1998). Acci 'on deferencial de dos formulaciones de azadiractina sobrelos estados de desarrollo de Ceratitis capitata (Wiedemann) (Dipetera: Tephritidae). Boletín de sanidad vegetal. Plagas, 24:1009-1018.

[3] Ahmed, S. and Grainge, M. (1986). Potential of the neem tree (Azadirachta indica) for pest control and rural development. Economy Botany, 40: 201-209.

[4] Amadioha A.C. (2000). Controlling rice blast in vitro and in vivo with extracts of Azadirachta indica, Crop Protection, 19: 287-290.

[5] Ananthakrishnan, T.N., Senrayan, R., Murugesan, S. and Annadurai, R.S. (1991).Kairomones of Heliothisarmigeraand Corcyra cephalonicaand their influence on the parasitic potential of Trichogrammachilonis (Trichogrammatidae: Hymenoptera). Journal of CommunicationsIssue, 1: 23-24.

[6] Bhatt, N.J. and Patel, R.K. (2001). Screening of chickpea cultivars for their resistance to gram pod borer, Helicoverpaarmigera. Indian Journal of Entomology, 63(3): 277 - 280.

[7] Bhonde, S.B., Deshpande, S.G. and Sharma, R.N. (1999). In vitro evaluation on inhibitory nature of some neem formulations against plant pathogenic fungi. Hindustan Antibiotic Bulletin 4:22-24.

[8] Dhakshinamoorthy, G. and Selvanarayana, V. (2002). Evaluation of certain natural products against pulse beetle, Callosobruchus maculates F. infesting stored green gram. Insect Environment, 8(1): 29-30.

[9] Dhyani, S., Tripathi, S. and Inder, D. (2004). Preliminary screening of neem (Azadirachta indica) leaf extractives against Poriamonticolad-a wood destroying fungus. Journal of Indian Academics Wood Science, 1-2: 103-112.

[10] Dubey, N.K. and Kumar, A. (2009). Exploitation of natural products in eco-friendly management of plant pests. Business media B.V., 181-198.

[11]Dutta, S. (2015). Biopesticides: An Ecofriendly approach for pest control. World journal of pharmacy and pharmaceutical sciences, 4(6): 250265.

[12]El-Sinary, N.H. and Rizk, S.A. (2002). Oviposition deterrence and other biological influences of aqueous leaves extracts of neem, colocasia and their mixtures alone or combined with gamma radiation to reduce the risk of the potato tuber moth, Phthorimaeaoperculella (Zeller). Pakistan Journal of Biological Science5 (9): 911-914.

[13] Gelernter, W. (2006). Biopesticides: visions vs. reality. From Presentation: 2006 (American Phytopathological Society Meeting). Quebec City, Quebec, Canada.

[14]Heidi, K. and Eileen, M.C. (2008). Insect growth regulator effect of azadirachtin and neem oil on survivorship, development and fecundity of Aphis glycines (Hemiptera: Aphididae) and its predator Harmoniaaxyridis (coleoptera: Coccinellidae). Pest Management science, society of chemical industry. Archived at http://orgprints.org/24349, pp. 660-668.

[15] Hirose, E., Neves, P.M.O., Zequl, J.A.C., Martins, L.H., Peralta, C.H. and Moino, A.J. (2000). Effects of biofertilizers and neem oil on the pathogenic fungi Beauvariabassiana (bals) vuill and Metarhiziumanisopliae (metsch.) sorok, Brazilian Archives of Biology and Technology, 44: 419-423.

[16] Isman, M.B., Koul, O., Luczynski, A. and Kaminski, J. (1990a). Insecticidal and antifeedant bioactivities of neem oil and their relationship to azadirachtin content. Journal of Agriculture and Food chemistry, 38: 1406-1411.

[17]Jogar, K., Metspalu, L., Hiiesaar, K., Loorits, L., Ploomi, A., Kiosk, A. and Luik, A. (2009). Influence of neem Azalea-T/S on Mamestra brassicae L. SodininkysteIr Darzininkyste., 28 (3): 85-92.

[18] Jonah, K.B. and Maingi, J. (2015). Invitro response of Phomopsistheae to the products of Azadirachta indica and extracts of Warburglaugandensis, unpublished.

[19] Kabissa, J.C.B. Kayumbo, H.Y. and Yapro, J.G. (1996). Seasonal abundance of chrysopids (Neuroptera: Chrysopidae) preying Helicoverpaarmigera (Hubner) (Lepidoptera: Noctuidae) and Aphis gossypii (Glover) (Homoptera: Aphididae) on cotton in eastern Tanzania. Crop Protection, 15: 5-8.

[20] Karen Peabody, O"Brien, K.P., Franjevic, S. and Jones, J. (2009). Green chemistry and sustainable agriculture the role of bio-pesticide, pp 50.

[21] Kovach, J., Petzoldt, C., Degni, J. and Tette, J. (1992). A method to measure the environmental impact of pesticides. Newyork's food and lifesciences bulletin, Cornell University, Ithaca, 139: 0362-0069.

[22] Krischik, V. and Davidson, J. (2007). Integrated pest management of northwest Landscapes. Minneapolis 
(MN): Regents of the University of Minnesota, 1(23-24): 315.

[23] Kumar, A., Paul, A.V.N., Zayeem, A. and Singh, A.K. (2011). The effect of leaf extracts of rice varieties on foraging behavior of Trichogrammabras iliensis and Trichogramma exiguum. Iranian Journal of Entomology, 1: 1-7.

[24] Kumar, A., Zayeem, A. and Kanameni, S. (2012). Synomonal effect of cole crops on individual and associative learning behaviour of Cotesiaplutellae. International Journal of Biology, Pharmacy and Allied Sciences 1: 285-298.

[25] Larson, R.O. (1989). The commercialization of neem, In M. Jacobson [ed.], Focus on phytochemical pesticides, The neem tree. CRC press, Boca Raton, FL., Vol.1. pp. 155-168.

[26] Lavender, D.P., Parish, R. Johnson, C.M. Montgomery, G. Vyse, A. Willis, R.A. and Winston, D. [eds.], (1990). Regenerating British Columbia's Forests. University of British Columbia Press, Vancouver, B.C.

[27] Lewis, W., van Lenteren, C., Phatak, S. and Tumlinsen, J. (1997). A total system approach to sustainable pest management. Proceedings of the National Academy of Science USA, 94: 1224312248.

[28]Liu, J., Wu, K., Hopper, K. and Zhao K. (2004). Population dynamics of Aphis glycines (Homoptera: Aphididae) and its natural enemies in soybean in Northern China. Annals of the Entomological Society of America, 97: 235-239.

[29] Mahmoud, M.F. and Shoeib, M.A. (2008). Sterilant and ovipositor deterrent activity of neem formulation on peach fruit fly Bactrocerazonata (Saunders) (Diptera: Tephritidae). Journal of Biopesticides, 1: 177-181.

[30] Mann, G.S., Dhaliwal, G.S. and Dhawan, A.K. (2001). Field efficacy of neem based insecticides against whitefly and their impact on insect pest complex of cotton. Pesticide Research Journal, 13: 79-81.

[31]Marian, J. and Sawchuk. (1994). An Environmentally friendly insecticide for conifer seed orchards. Simon Fraser University, unpublished.

[32] Mathur SC. (1999). Future of Indian pesticides industry in next millennium. Pesticide Information. 24(4):9-23.

[33] Md. Wasim Aktar, Dwaipayan sengupta and Ashim chowdhury (2009). Impact of pesticides use in agriculture: their benefits and hazards. Interdisciplinary toxicology, 2(1):1-12.

[34] Mordue, A.J. and Nisbet, A.J. (2000). Azadirachtin from the neem tree Azadirachta indica: its actions against insects. Anais da Sociedade Entomológica do Brazil, 29: 615-632.

[35] Mukhopadhyay, A.N., Shrestha, A.M. and Mukherjee, P.K. (1992). Biological seed treatment for the control of soil-borne plant pathogens. FAO Plant Protection Bulletin, 40: 21-30.

[36] Nathan, S.S., Kalaivani, K. and Murugan, K. (2006). Effect of biopesticides on the lactate dehydrogenase $(\mathrm{LDH})$ of the rice leaf folder, Cnaphalocrocismedinalis (Guenée) (Insecta: Lepidoptera: Pyralidae). Ecotoxicology and Environmental Safety, 65(1): 102-107.

[37] Nerio, L.S., Olivero, J.V. and Stashenko, E.S. (2009). Repellent activity of essential oils from seven aromatic plants grown in Colombia against Sitophiluszeamais Motschulsky (Coleoptera). Journal of Stored Product Research, 45: 212-214.

[38] Okigbo, R.N. and Nmeka, I.A. (2005). Control of Yam tuber rot with leaf extracts of Xylopiaaethiopica and Zingiber officinale. African Journal of Biotechnology, 14: 804-807.

[39] Petel, T., Jakhmola, S.S. and Bhadauria, N.S. (2004). Effect of plant materials on rice weevil (SitophilusoryzaeL.) in wheat. Indian Journal of Entomology, 66(2): 99-101.

[40] Poiloakidou, E. (2005). Biological control of powdery mildew, Pedoshaeraxanthii, on cucumber using plant extracts neem and Alicin, Honours thesis, University of Aberdeen Phytopathology100: 9913-9921.

[41] Rabindra, R.J. (2005). Current status of production and use of microbial pesticides in India and the way forward. In Rabindra, R.J., Hussaini, SS. and Ramanujam, B. (ed.), Microbial Biopesticde Formulations and Applications. Project Directorate of Biological Control, Technical Document No. 55: 1-12.

[42] Ragsdale, D.W., McCornack, B.P., Venette, R.C., Potter, B.D., Macrae, I.V., Hodgson, E.W., et al., (2007). Economic threshold for soybean aphid (Hemiptera: Aphididae). Journal of Economic Entomology, 100: 1258-1267.

[43] Ragsdale, D.W., Voegtlin, D.J. and O’Neil, R.J., (2004). Soybean aphid biology in North America. Annals of the Entomological Society of America, 97: 204-208.

[44] Rahaman, G.M. and Motoyama, N. (2000). Repellent effect of garlic against stored product pest. Journal of Pesticide Science,25(3): 247-252.

[45] Roychowdhury, D., Paul, M. and Banerjee, S.M. (2014). A review on the effects of Biofertilizers \& Biopesticides on Rice and Tea cultivation and productivity. International Journal of Science, 
Engineering and Technology. V2, Issue 8.23484098.

[46] Salas, J. (2001). Efficacy of a garlic best repellent on the reduction of whitefly (Bemisiatabaci) populations. Agron. Trop. Marc., 51 (2): 163-174.

[47] Salma, M., Kalita, J., Rajkhowa and Ratul. (2011). A review on the use of biopesticides in insect pest management. International Journal of Science and Advanced Technology (ISSN 2221-8386), V1 (7).

[48] Saxena, R.C., Jilani, G. and Abdul Kareem, A. (1989). Effects of neem on stored grain insects, In Jacobson, M. [Ed.]. Focus on phytochemical pesticides. The neem tree. CRC press, Boca Raton, FL., 1: 97-111.

[49] Schmutterer, H. (1990). Properties and potential of natural pesticides from the neem tree, Azadirachta indica. Annual Review of Entomology, 35: 271-297.

[50] Stark, J.D. and Walter, J.F. (1995). Neem oil and neem oil components affect efficacy of commercial neem insecticides. Journal of Agriculture and Food Chemistry, 43: 507-512.

[51] Stark, J.D. and Rangus, T.M. (1994). Lethal and sublethal effects of the neem insecticide formulation, 'Margosan-O', on the pea aphid. Pesticide Science, 41: 155-160.

[52] Stark, J.D. and Wennergren, U. (1995). Can population effects of pesticides be predicted from demographic toxicological studies? Journal of Economic Entomology, 88: 1089-1096.

[53] Sun, B., Liangm S.B. and Zhao, W.X. (2000). Outbreaks of soybean aphid in Suihua district in 1998 and its control strategies. Soybean Bulletin, 8:5.

[54] Tang, Y.Q., Weathersbee, A.A. and Mayer, R.T. (2002). Effect of neem seed extract on the brown citrus aphid (Homoptera: Aphididae) and its parasitoid Lysiphlebus testaceipes (Hymenoptera: Aphidiidae). Environmental Entomology, 31:172176.

[55] Thakore, Y. (2006). The biopesticides market for global agricultural use. Industrial. Biotechnology, 2(3):192- 208.

[56] Vinod, K. (2015). A review on efficacy of biopesticides to control the agricultural insect's pest. International Journal of Agricultural Science Research, 4(9): 168-179.

[57] Wang, Y., Braman, S.K., Robacker, C.D., Latimer, J.G. and Espelie, K.E. (1999). Composition and variability of epicuticular lipids of azaleas and their relationship to azalea lace bug resistance. Journal of American Society of Horticulture Science, 124: 239244.
[58] Weathersbee, A.A., Hardee, D.D., Meredith- Junior, W.R. (1995). Differences in yield response to cotton aphids (Homoptera: Aphididae) between smooth leaf and hairy-leaf isogenic cotton lines. Journal of Economic Entomolgy, 88:749-754. 